\title{
Uromyces umiamensis, a new rust species on Momordica cochinchinensis in India
}

\section{Journal Article}

Author(s):

Berndt, Reinhard; Baiswar, Pankaj

Publication date:

2009

Permanent link:

https://doi.org/10.3929/ethz-b-000019974

Rights / license:

In Copyright - Non-Commercial Use Permitted

Originally published in:

Mycological Progress 8(2), https://doi.org/10.1007/s11557-008-0580-2 


\title{
Uromyces umiamensis, a new rust species on Momordica cochinchinensis in India
}

\author{
Reinhard Berndt $\cdot$ Pankaj Baiswar
}

Received: 17 October 2008 /Revised: 9 December 2008 / Accepted: 9 December 2008 / Published online: 13 January 2009

(C) German Mycological Society and Springer-Verlag 2009

\begin{abstract}
Uromyces umiamensis is described as a new rust fungus (Basidiomycota, Uredinales) of Momordica cochinchinensis (Cucurbitaceae) from Meghalaya, in northeastern India. The species differs from the known Uromyces species on members of Cucurbitaceae in terms of the character of the teliospores and aeciospores and its apparently demicyclic life cycle. Besides U. yakushimensis and the present species, all Uromyces species known from cucurbits occur in the New World. A key to known Uromyces species on Cucurbitaceae is provided.
\end{abstract}

Keywords Cucurbitaceae $\cdot$ Indian rust mycobiota .

Rust fungi

\section{Introduction}

Recently, a Uromyces species was collected on Momordica cochinchinensis Spreng. in northeastern India. The host plant is cultivated in southern and southeastern Asia for its edible fruits, oil-rich seeds and roots containing saponins. The present rust is the only known Uromyces species on the genus Momordica and the second known Uromyces on cucurbits in Asia. It was compared to the already described Uromyces species on members of Cucurbitaceae and found

R. Berndt $(\bowtie)$

Institute of Integrative Biology (IBZ),

ETH Zürich, CHN D 37,

Universitätstrasse 16,

8092 Zürich, Switzerland

e-mail: reinhard.berndt@env.ethz.ch

P. Baiswar

Division of Plant Pathology,

ICAR Research Complex for NEH Region,

Barapani 793103 Meghalaya, India to be different. A new species, U. umiamensis, is therefore proposed for it.

\section{Material and methods}

Spores and hand sections of herbarium material were embedded in a droplet of lactophenol solution on a microscopic slide glass and gently heated to facilitate soaking of the fungal structures. The preparations were examined with an Olympus BX51 light microscope and micrographs taken with a ColorView IIIu camera. The "Cell*B" software package (Software Imaging System $\mathrm{GmbH}$ ) was used to capture and edit micrographs. Photographs of rust sori were taken with the Color View IIIu on a Zeiss Stemi SV 8 dissecting microscope. Measurements were made with an ocular micrometer scale and are given to $0.5 \mu \mathrm{m}$. At least 30 spores were measured for each spore state.

For the designation of the spore states of the present species, we used terms based on the morphology of the sori, i.e. 'aecidia' and 'telia'.

\section{Taxonomy}

Uromyces umiamensis R. Berndt \& P. Baiswar, spec. nov. (Figs. 1 and 2)

Etymology: Named for the village of Umiam in the Meghalaya Hills, which was the collection site of the rust.

Spermogonia et uredinia absentia. Aecidia singularia vel dense aggregata praecipue abaxialia rariter adaxialia in maculis foliorum non vel vix incrassatis, primum bullata et cupuliformia, aperta cyathiformia, copia sporarum alba in herbario sicco, peridio fragili albo recurvato et lacerato circumdata; aecidio- 

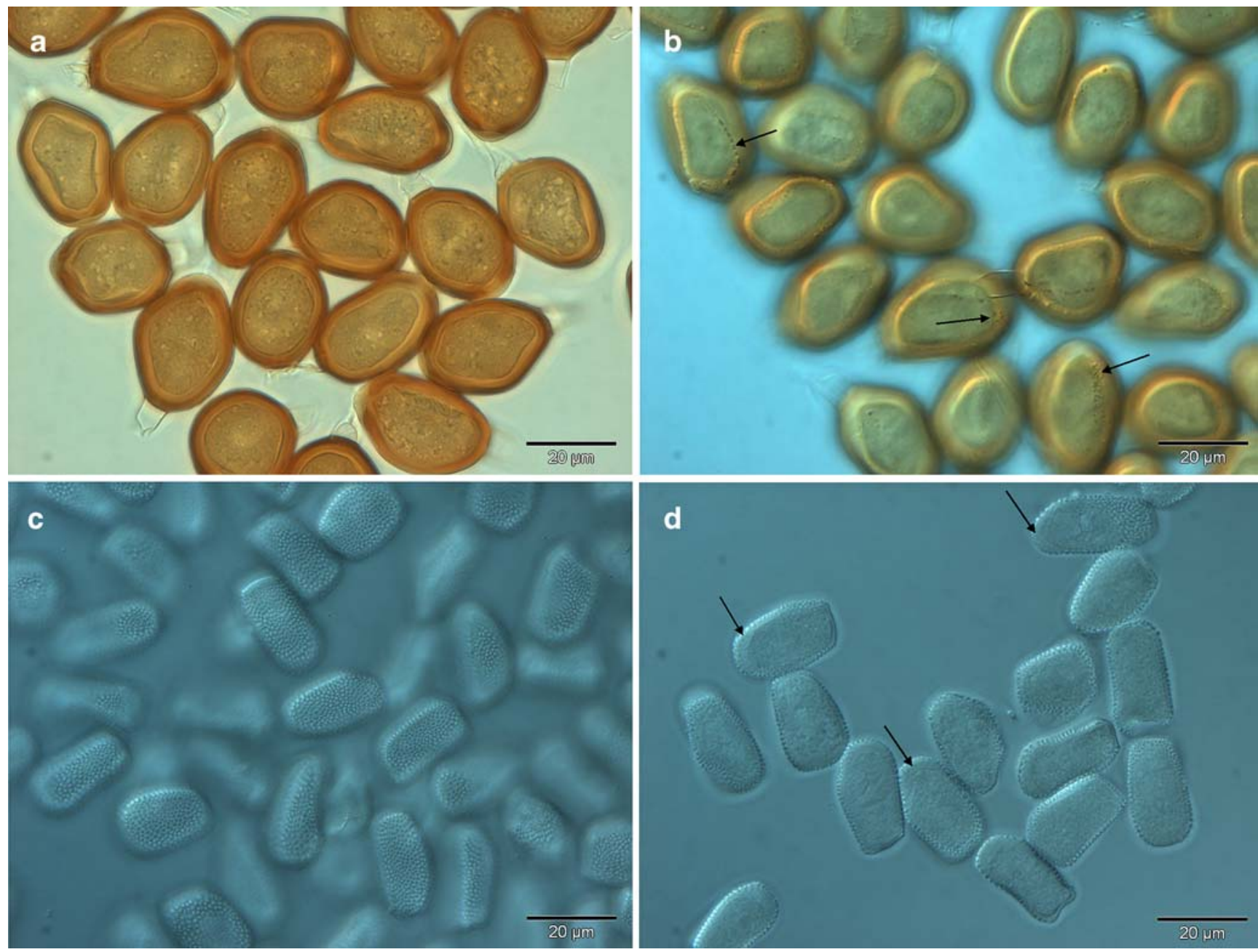

Fig. 1 Uromyces umiamensis (isotype, ZT Myc 486). a. Teliospores, optical section. b. Teliospores, focus on spore surface showing lines, bands or groups of delicate warts (arrows) on otherwise smooth

spores. c. Aecidiospores, focus on spore surface. d. Aecidiospores, optical section. Note apically thickened aeciospore wall (arrows)

sporae plusminusve cuboideae subangulariter ellipsoideae vel late ellipsoideae $20-28 \times 12-16 \mu \mathrm{m}(23.8 \times 14.6 \mu \mathrm{m})$, pariete hyalino ca. $1.5 \mu \mathrm{m}$ crasso usque ad $2.5-4 \mu \mathrm{m}$ crasso in parte apicali, sate delicate dense et regulariter verruculoso, poris germinationis non visis; cellulae peridii compressae plus minusve rectangulares, intus verrucis irregularibus et moderate delicatis dense copertae, extus subleves. Telia in gregibus parvis saepe concentrice disposita aeciis opposita in pagina adaxiali foliorum, epidermide cinerea diu tecta bullata, deinde aperta pulverulenta et castanea; teliosporae irregulari formae sed generaliter late ellipsoideae vel obovoideae $26-33 \times 19$ $25 \mu \mathrm{m}(29.0 \times 22.1 \mu \mathrm{m})$, pedicello hyalino tenue tunicato brevi, pariete ca. 2.5-3 $\mu \mathrm{m}$ crasso dilute castaneo vel aurantiaco-brunneo sublevi, verrucis parvis saepe in lineis longitudinalibus dispositis ornato, poro germinationis apicali, papilla lata humilique praedito.

In foliis Momordicae cochinchinensis (Cucurbitaceae).

Spermogonia and uredinia not present. Aecidia mainly on the abaxial, rarely on the adaxial side of the leaves,

singly or in small, dense groups on leaf spots that are slightly hypertrophied or not, bullate and cupola-shaped as long as closed, cup-shaped when open, spore mass white in dried specimen, surrounded by a fragile, white, recurved and lacerated peridium; aecidiospores often more or less cuboid, subangularly ellipsoid or broadly ellipsoid, 20-28× 12-16 $\mu \mathrm{m}$ (mean $23.8 \times 14.6 \mu \mathrm{m}$ ), spore wall hyaline, ca. $1.5 \mu \mathrm{m}$ thick, at distal spore end thickened to $2.5-4 \mu \mathrm{m}$, rather finely, densely and evenly verruculose, germ pores not observed; peridial cells compressed, more or less rectangular, covered by moderately fine, irregularly shaped warts on inner tangential wall, smooth or inconspicuously rugulose on outside. Telia in small groups, sometimes almost concentrically arranged on adaxial side of leaves, opposite of the aecidia, subepidermal, bullate and ash grey while covered by the epidermis, pulverulent and chestnut brown after epidermis has ruptured; teliospores slightly irregularly shaped, often broadly ellipsoid or obovoid, with thin-walled, hyaline pedicel which tends to break off 

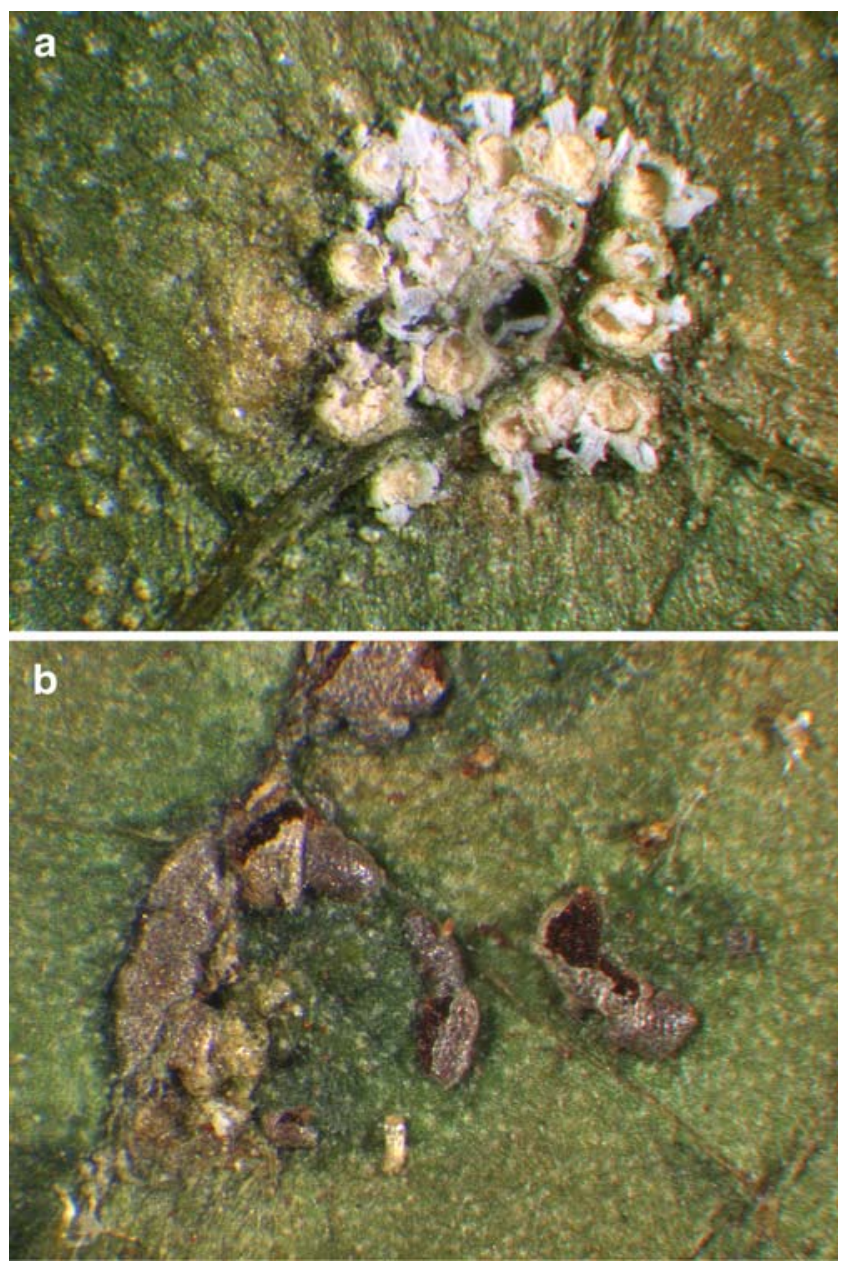

Fig. 2 Uromyces umiamensis (isotype, ZT Myc 486). a. Group of aecidia on abaxial leaf surface. b. Telia on adaxial leaf surface, partly covered by epidermis, partly open

shortly from the hilum, 26-33×19-25 $\mu$ m (mean $29.0 \times$ $22.1 \mu \mathrm{m}$ ), spore wall ca. 2.5-3 $\mu \mathrm{m}$ thick, light chestnut brown to orange brown, almost smooth but generally with a few longitudinal or oblique rows or groups of delicate warts, germ pore apical, covered by a broad and flat cap.

On leaves of Momordica cochinchinensis (Cucurbitaceae).

Holotype (IMI 396239): India, Meghalaya State, Barapani, village of Umiam, $25^{\circ} 30^{\prime} \mathrm{N} / 91^{\circ} 51^{\prime} \mathrm{E}$, on $M$. cochinchinensis, leg. P. Baiswar, June 2007 (Isotypes AMH 9229, MACS-Agharkar Research Institute, Maharashtra, India and ZT Myc 486, Zurich, Switzerland).

The rust fungi reported on Momordica are Puccinia cucumeris Henn., P. momordicae Kalchbr. \& Cooke, P. vanderystii Henn., Aecidium charantiae Mayor \& Vienn.Bourgin and A. momordicae Juel. U. umiamensis is the first Uromyces sp. found on this host genus. Ten species of Uromyces have been recognized so far on members of Cucurbitaceae to our knowledge: $U$. anguriae Jacks. \& Holw. on Anguria in South America, U. corallocarpi Dale on Corallocarpus in Mexico and the Caribbean, U. guraniae on
Gurania in South America, U. neotropicalis Hern. \& Aime on Cayaponia in South America, U. novissimus Speg. (=U. appelianus Gasser, U. hellerianus Arthur) on several genera of cucurbits in South and Central America and Puerto Rico, U. pentastriatus Viégas on Trianosperma in Brazil, $U$. poliotelis H. Syd. on Anguria in Central America, U. ratoides Jørstad on Cayaponia in South America, U. ratus Jacks. \& Holw. on Cayaponia in South America, and U. yakushimensis Hirats. \& Kats. on Trichosanthes in Japan. All these species differ from $U$. umiamensis in several spore characters and by another life cycle. Besides $U$. yakushimensis all enumerated Uromyces species on Cucurbitaceae occur in the New World, especially the Neotropis. We did not check the identity of Aecidium charantiae and A. momordicae, which were described from Ivory Coast and Brazil, respectively, with any of the telial rusts on cucurbits.

The following key is based on the original species descriptions and data from other important literature (e. g., Jackson 1932; Jørstad 1956; Monoson and Rogers 1978; Sydow and Sydow 1910); its intention is to help distinguish the present from similar Uromyces species on Cucurbitaceae.

1 Life cycle with aecidia ................................................. 2

2 Demicyclic, with aecidia and telia. Teliospores 26 $33 \times 19-25 \mu \mathrm{m}$, almost smooth but with rows, bands or groups of fine warts; apical cap subhyaline, flat and broad. On Momordica (India) ............... U. umiamensis

2* Macrocyclic, usually with Uredo-like uredinia. Teliospores larger, $27-38 \times 24-27 \mu \mathrm{m}[(24) 35-43 \times 28$ $38 \mu \mathrm{m}$ acc. to Monoson \& Rogers], smooth or most finely verruculose-rugose, with a 6-12 $\mu \mathrm{m}$ high papilla; aecidial characters uncertain. On Anguria (Brazil) ................................................... U. anguriae

$1 *$ Life cycle without aecidia, or aecidia unknown. Uredolike uredinia and/or telia present ................................. 3

3 Teliospores on average longer than $35 \mu \mathrm{m} \ldots .$.

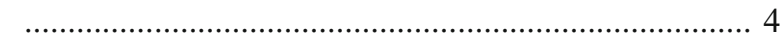

4 Teliospores fusiform to ellipsoid, 39-80×16-33 $\mu \mathrm{m}$. On cf. Cayaponia (Ecuador) ...................... U. ratoides

4* Teliospores subglobose, ovoid or pyriform, 36-51 $\times 27$ $33 \mu \mathrm{m}$. On Trichosanthes (Japan)

U. yakushimensis

3* Teliospores on average shorter than $35 \mu \mathrm{m}$

................................................................. 5

5 Teliospore wall either with a few longitudinal ridges or finely verrucose .......................................................... 6

6 Teliospore wall with a few longitudinal ridges ("striate verrucose" acc. to Monoson \& Rogers). On Trianosperma (Brazil) U. pentastriatus

6* Teliospore wall finely verrucose. On Corallocarpus (West Indies, Mexico) ......................... U. corallocarpi

$5^{*}$ Teliospores not longitudinally ridged or verrucose, at most with some short lines, generally smooth. 
7 Teliospores on average shorter than $27 \mu \mathrm{m}$ 8

8 Teliospores $19-26.5 \times 16.5-20 \mu \mathrm{m}$, apex ca. $2-3 \mu \mathrm{m}$ thick; urediniospores globose, $21.5-29 \times 21.5-29 \mu \mathrm{m}$, with 2 equatorial germ pores. On Cayaponia (Guyana) U. neotropicalis

8* Teliospores $16-24 \times 15-19 \mu \mathrm{m}$, apex thickened to $7 \mu \mathrm{m}$; urediniospores 19-26×15-19 $\mu \mathrm{m}$, with 2 equatorial germ pores. On Gurania (Colombia)

.................................................. U. guraniae

$7^{*} \quad$ Teliospores on average longer than $27 \mu \mathrm{m}$ 9

9 Teliospores with an up to $8 \mu \mathrm{m}$ high apical papilla. On a number of genera of cucurbits (warm regions of New World) U. novissimus

9* Teliospore apex rounded or umbonate, slightly to considerably thickened at apex, but not with a distinct high papilla .. 10

10 Teliospore apex rounded, 2-3 $\mu \mathrm{m}$ thick, teliospores 24-30×22-26 $\mu \mathrm{m}$ On cf. Anguria (Costa Rica) U. poliotelis
10* Teliospore apex thicker, prominently umbonate, telio-

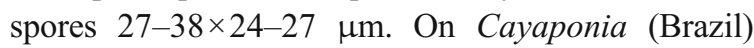
U. ratus

\section{References}

Jackson HS (1932) The rusts of South America based on the Holway collections - VI. Mycologia 24:62-186. doi:10.2307/3753730

Jørstad I (1956) Uredinales from South America and tropical North America chiefly collected by Swedish botanists. Arkiv för Botanik (2. ser.) 3:443-490

Monoson HL, Rogers GM (1978) Species of Uromyces that infect New World Cucurbitaceae. Mycologia 70:1144-1150. doi: $10.2307 / 3759312$

Sydow P, Sydow H (1910) Monographia Uredinearum. Vol. II. Genus Uromyces. Gebrüder Bornträger, Leipzig 